Vol 2. No 1. Januari 2022 P-ISSN : 2774-8022, e-ISSN : 2774-5791

\title{
PENGEMBANGAN MEDIA E-BOOK AUDIO VISUAL MENGGUNAKAN FLIPBOOK MATERI TRIGONOMETRI KELAS XI IPA BERBASIS HYBRID LEARNING
}

\author{
QURROTUL UYUN \\ SMA Muhammadiyah 1 Taman \\ e-mail: uuyuun04@gmail.com
}

\begin{abstract}
ABSTRAK
Pandemi covid-19 yang melanda dunia sejak tahun 2019 mengakibatkan dunia pendidikan di Indonesia yang awalnya diharuskan melakukan pembelajaran secara daring atau dalam jaringan yang dilakukan dirumah hingga saat ini kasus covid di Indonesia semakin menaurun akhirnya dinas pendidikan memberlakukan sistem pembelajaran secara hybrid atau pembelajaran luring dan daring. Solusi untuk pembelajaran hybrid melalui beberapa aplikasi seperti Whatsapp grup, Zoom, Google classroom, Google meet, Quipper dan lain sebagainya. Dengan aplikasi tersebut guru dituntut kreatif dalam menyampaikan pembelajaran secara hybrid, oleh karena itu selain menggunakan aplikasi tersebut peneliti menggunakan flipbook untuk penunjang pembelajaran hybrid. Metode pada penelitian ini menggunakan ADDIE yaitu Analisis, Design, Development, Implementasi dan Evaluasi. Tujuan dari penelitian ini untuk memberikan pembelajaran bermakna serta menyenangkan dan tidak membosankan tanpa memberikan tugas yang terlalu berat sehingga membuat peserta didik tidak nyaman karena banyak tugas dan terlalu banyak materi yang disampaikan dengan cara monoton. Hasil dari validasi tim ahli didapat sebesar $86,5 \%$ dengan artian e-book sangat layak digunakan dan mendapat respon positif dengan nilai presentase $89,5 \%$ menghasilkan respon positif. Kesimpulan yang dapat dikerucutkan adalah pembelajaran daring secara e-learning menggunakan Flipbook dengan materi trigonometri kelas XI IPA dinyatakan efektif karena peserta didik dapat paham materi trigonometri meskipun pembelajaran dilakukan secara hybrid
\end{abstract}

Kata Kunci: Pembelajaran hybrid, E-Book, Pandemi Covid-19, Flipbook, Trigonometri

\section{ABSTRACT}

The COVID-19 pandemic that has hit the world since 2019 has resulted in the world of education in Indonesia, which was initially required to conduct online or online learning at home. Until now, the number of Covid cases in Indonesia has decreased. Finally, the education office has implemented a hybrid learning system or offline and online learning. . Solutions for hybrid learning through several applications such as Whatsapp groups, Zoom, Google classroom, Google meet, Quipper and so on. With this application, teachers are required to be creative in delivering hybrid learning, therefore in addition to using this application, researchers use flipbooks to support hybrid learning. The method in this study using ADDIE namely Analysis, Design, Development, Implementation and Evaluation. The purpose of this study is to provide meaningful and fun learning and not boring without giving assignments that are too heavy so that it makes students uncomfortable because there are many assignments and too much material is delivered in a monotonous way. The results from the validation of the expert team were obtained at $86.5 \%$, which means that the e-book is very suitable to be used and received a positive response with a percentage value of $89.5 \%$ resulting in a positive response. The conclusion that can be narrowed is that e-learning online learning using Flipbook with trigonometry material for class XI Science is declared effective because students can understand trigonometry material even though the learning is done in a hybrid way.

Keywords: Hybrid learning, E-Book, Covid-19 pandemic, Flipbook, Trigonometry

\section{PENDAHULUAN}

Perkembangan teknologi informasi memiliki pengaruh besar terhadap perubahan dalam setiap bidang. Salah satunya ialah perubahan pada bidang pendidikan. Teknologi dapat 
dimanfaatkan dalam kegiatan proses belajar mengajar, yang dapat dikatakan merupakan pergantian dari cara konvensional menjadi ke modern. (Gheytasi, Azizifar \& Gowhary (dalam Khusniyah dan Hakim, 2019:21) menyebutkan bahwa beberapa penelitian menunjukkan bahwa dengan adanya teknologi memberikan banyak pengaruh positif terhadap pembelajaran. Internet telah dipadukan menjadi sebuah alat yang digunakan untuk melengkapi aktivitas pembelajaran (Martins,2015). Pembelajaran daring merupakan sistem pembelajaran yang dilakukan dengan tidak bertatap muka langsung, tetapi menggunakan platform yang dapat membantu proses belajar mengajar yang dilakukan meskipun jarak jauh. Tujuan dari adanya pembelajaran daring ialah memberikan layanan pembelajaran bermutu dalam jaringan yang bersifat masif dan terbuka untuk menjangkau peminat ruang belajar agar lebih banyak dan lebih luas (Sofyana \& Abdul, 2019:82).

Pengembangan hybrid juga mengarah pada bahan ajar yang digunakan. Bahan ajar yang digunakan salahsatunya berupa modul dalam kemasan elektronik. Dalam pembelajaran berbasis web modul elektronik ini dikenal dengan istilah bahan ajar mandiri atau bahan ajar yang dikemas untuk mahapeserta didik belajar mandiri. Di dalam bahan ajar mandiri selain materi juga disediakan latihan-latihan yang harus dikerjakan mahapeserta didik untuk mengukur perkembangan belajarnya. Dalam pembelajaran hybrid, selain bahan ajar modul elektronik, dalam proses belajarnya mahapeserta didik juga memanfaatkan bahan ajar berbasis web. (Desprayoga, 2019)

Selain itu menurut (Sanjaya, 2006) Sumber belajar adalah segala sesuatu yang dapat dimanfaatkan oleh siswa untuk mempelajari bahan dan pengalaman belajar sesuai dengan tujuan yang hendak dicapai. Sumber belajar pada dasarnya dipakai dalam pendidikan atau latihan sebagai suatu sistem yang terdiri dari sekumpulan bahan atau situasi yang diciptakan dengan sengaja dan dibuat agar memungkinkan siswa belajar secara individual. (Ellington, 1988)

Sampai saat ini pada pembelajaran hybrid sebanyak 75\% guru di SMA Muhammadiyah 1 Taman paling banyak menyampaian materi menggunakan googleclassroom dan Zoom. Untuk pembelajaran matematika juga yang lebih sering digunakan adalah aplikasi zoom dikarenakan zoom memiliki fitur untuk menulis rumus dan membahas soal menggunakan tangan seperti menulis dipapan tulis, akan tetapi kendala nya adalah media untuk menulisnya terlalu kecil dan tidak seluasa seperti papan tulis. Kemudian untuk zoom yang biasa digunakan oleh guru-guru adalah metode ceramah dan metode power point. Hal tersebut membuat para peserta didik menjadi jenuh dengan pembelajaran model tersebut.

Aplikasi lain yang digunakan untuk penunjang pembelajaran hybrid disaat pandemi selain powerpoint, microsoft word, zoom, googlemeet atau lainnya adalah flipbook. Pada flipbook terdapat suatu fitur animasi ataupun audio dan video audio visual yang disampaikan oleh guru pengajar. Penggunaan zoom yang banyak sekali kendala yang dialami pada saat pembelajaran hybrid seperti jaringan peserta didik/guru error atau bermasalah. Sehingga penjelasan guru tidak tersampaikan dengan baik. Belum lagi permasalahan untuk peserta didik yang belum berkecukupan untuk membeli pulsa paketan, karena untuk menggunakan zoom harus memerlukan paketan ekstra. Oleh karena itu alternatif mengatasi masalah tersebut maka guru matematika menggunakan flipbook untuk media penunjangnya supaya materi dapat disampaikan dengan baik. Apalagi pelajaran matematika juga kerap tidak disukai oleh para peserta didik dikarenakan materinya yang dianggap susah.

Hal ini dikemukakan oleh (Putra T. A., 2018) Namun dalam pembelajaran matematika sebagian besar peserta didik menganggap matematika merupakan mata pelajaran yang sangat sulit karena di dalam pembelajaran matematika banyak rumus dan perhitungan yang berfungsi sebagai penyelesaian masalah dan juga matematika merupakan salah satu mata pelajaran yang membosankan oleh sebagian peserta didik karena dalam pelajaran matematika hanya menemukan angka, rumus, maupun grafik sehingga membuat anak- anak kurang berminat dan membosankan dengan pelajaran matematika tersebut terutama dalam hal mata pelajaran trigonometri. 
Dikarenakan hal diatas peneliti berinovasi membuat media pembelajaran berupa e-book audio visual dengan materi trigonometri kelas XI IPA menggunakan aplikasi flipbook. Menurut (Sarah, 2018) E-book adalah singkatan dari Electronik Book. E-book adalah sebuah jenis buku elektronik yang berbentuk softcopy yang dapat dibuka secara elektronik melalui komputer dan handphone.E-book dapat berupa file dengan format yang bermacam-macam. Ada berupa htm yang dapat dibuka dengan browsing, ada juga berupa pdf yang dapat dibuka dengan program Acrobat Reader atau sejenisnya. Tujuan dari penelitian ini adalah untuk mengembangkan media e-book yang efisien dan bisa gunakan peserta didik untuk pembelajaran hybrid yang menyenangkan, bermakna dan tidak membosankan.

\section{METODE PENELITIAN}

Metode penelitian yang peneliti gunakan adalah metode penelitian R\&D (Research and Development) dengan pengembangan ADDIE. Metode penelitian dan pengembangan (research and development) adalah metode penelitian yang digunakan untuk menghasilkan produk tertentu. Menurut Borg and Gall, yang dimaksud dengan model penelitian dan pengembangan adalah "a process used develop and validate educational product". Bahwa penelitian pengembangan sebagai usaha untuk mengembangkan dan memvalidasi produk-produk yang digunakan dalam proses pembelajaran (Purnama, 2013). Model ini menggunakan 5 tahap pengembangan yakni: Analysis (analisis), Design (Desain), Development (Pengembangan), Implement (Implementasi), dan Evaluate (Evaluasi)

Peneliti menggunakan subjek dengan skala kecil yaitu peserta didik kelas XI IPA SMA Muhammadiyah Taman kemudian untuk metode ADDIE dengan tahap análisis peneliti menggunakan observasi berupa pengamatan langsung pada saat pembelajaran matematika serta melakukan observasi berupa angket kepada 20 guru SMA Muhammadiyah 1 taman untuk mengetahui media atau aplikasi yang digunakan pada saat pembelajaran hybrid. Pada tahap desain, peneliti membuat e-book dengan materi trigonometri kelas XI IPA menggunakan aplikasi canva dengan berbagai fitur desain dan dikembangkan menggunakan flipbook disertai penambahan video audio visual.

Selanjutnya pada tahap development peneliti merancang dan mendesain e-book menggunakan canva kemudian di upload ke flipbook untuk menjadikan file ke dalam bentuk ebook, setelah itu peneliti akan memberikan produk buat kepada tim ahli untuk kevalidan ebook. Untuk penilaian validasi tim ahli menggunakan skala likert seperti terlihat pada Tabel 1. (Sugiyono, 2017)

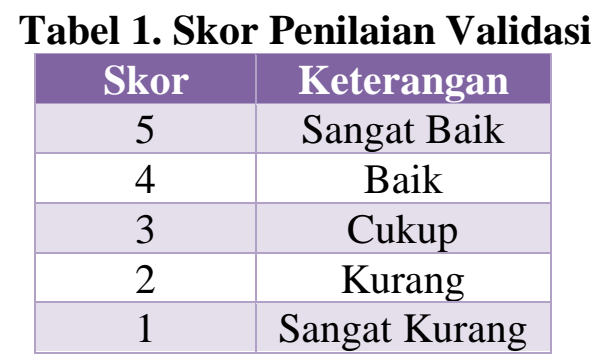

Hasil validasi yang tertera dalam lembar validasi e-book trigonometri akan dianalisa menggunakan rumus sebagai berikut :

$$
P(\text { Angka presentasi data })=\frac{\text { Jumlah yang diperoleh }}{\text { Jumlah skor maksimum }} \times 100 \%
$$

Kemudian hasil dari presentasi validasi akan dikelompokkan dalam kriteria kelayakan seperti terlihat pada Tabel 2 (Putra T. A., 2018). Sehingga diperoleh kesimpulan tentang kelayakan produk e-book trigonometri.

Tabel 2. Kriteria Kelayakan Produk

\begin{tabular}{|c|c|}
\hline Skor rata-rata & Kategori \\
\hline $\mathbf{8 0} \%<\boldsymbol{x} \leq \mathbf{1 0 0} \%$ & Sangat layak \\
\hline $\mathbf{6 0} \%<\boldsymbol{x} \leq \mathbf{8 0} \%$ & Layak \\
\hline
\end{tabular}


Vol 2. No 1. Januari 2022 P-ISSN : 2774-8022, e-ISSN : 2774-5791

$$
\begin{array}{c|c}
\mathbf{4 0} \%<\boldsymbol{x} \leq \mathbf{6 0} \% & \text { Cukup layak } \\
\hline \mathbf{2 0} \%<\boldsymbol{x} \leq \mathbf{4 0} \% & \text { Tidak layak } \\
\mathbf{0} \% \leq \boldsymbol{x} \leq \mathbf{2 0} \% & \text { Sangat tidak layak } \\
\hline
\end{array}
$$

Pada tahap implementasi, peneliti akan melakukan uji coba produk kepada peserta didik pada saat melakukan pembelajaran matematika. Tahap terakhir adalah evaluasi yaitu penilaian yang dilakukan oleh peserta didik melalui angket dengan kategori penilaian pada Tabel 3.

Tabel 3. Penilaian angket responden

\begin{tabular}{|c|c|}
\hline Pilihan Jawaban & Skor \\
\hline Sangat Setuju (SS) & 5 \\
\hline Setuju (S) & 4 \\
\hline Kurang Setuju (KS) & 3 \\
\hline Tidak Setuju (TS) & 2 \\
\hline Sangat Tidak Setuju (STS) & 1 \\
\hline
\end{tabular}

Hasil angket dan siswa akan dianalisa menggunakan rumus sebagai berikut:

$$
P(\text { Angka presentasi data })=\frac{\text { Jumlah yang diperoleh }}{\text { Jumlah skor maksimum }} \times 100 \%
$$

Kemudian hasil dari presentasi validasi akan dikelompokkan dalam kriteria ketertarikan responden terhadap produk seperti terlihat pada Tabel 4. Sehingga diperoleh kesimpulan tentang ketertarikan responden terhadap produk e-book trigonometri.

Tabel 4. Kriteria Ketertarikan Responden

\begin{tabular}{|c|c|}
\hline Skor rata-rata & Kategori \\
\hline $\mathbf{8 0} \%<\boldsymbol{x} \leq \mathbf{1 0 0} \%$ & Sangat Menarik \\
\hline $\mathbf{6 0} \%<\boldsymbol{x} \leq \mathbf{8 0} \%$ & Menarik \\
\hline $\mathbf{4 0} \%<\boldsymbol{x} \leq \mathbf{6 0} \%$ & Cukup Menarik \\
\hline $\mathbf{2 0} \%<\boldsymbol{x} \leq \mathbf{4 0} \%$ & Tidak Menarik \\
\hline $\mathbf{0} \% \leq \boldsymbol{x} \leq \mathbf{2 0} \%$ & Sangat tidak Menarik \\
\hline
\end{tabular}

\section{HASIL DAN PEMBAHASAN}

\section{Hasil}

Berdasarkan penelitian menggunakan pengembangan ADDIE yaitu Analysis (analisis), Design (Desain), Development (Pengembangan), Implement (Implementasi), dan Evaluate (Evaluasi) yaitu didapat hasil sebagai berikut

\section{a. Analysis (Analisis)}

Tahap analisis yang dilakukan penelitia adalah melakukan pengamatan langsung kepada guru-guru di SMA Muhammadiyah 1 Taman mengenai aplikasi atau media pembelajaran yang digunakan selama pembelajaran hybrid dan didapat sebesar $72 \%$ masih banyak menggunakan zoom dengan model ceramah dan hanya menggunakan aplika penunjang untuk memberikan tugas di google classroom. Selain kepada guru, penelitia juga melakukan obervasi kepada peserta didik berupa pengamatan langsung dan didapat bahwa peserta didik merasa bosan dengan model pembelajaran yang diterapkan guru dengan cara yang sama dan tidak ada variasa atau inovasi baru

\section{b. Design (Desain)}

Tahap Desain menggunakan aplikasi canva untuk mendesain animasi serta tulisannya kemudian dilanjut dijadikan e-book menggunakan Flipbook. Flipbook yang peneliti gunakan untuk menunjang pembelajaran daring selain zoom ataupun powerpoint yang ditampilkan di zoom. Maka produk berupa flipbook untuk materi trigonometri mempunyai 16 halaman dengan menggunakan desain di applikasi canva yang dapat di download di Appstore. Penggunaan flipbook dapat digunakan melalui mobile atau handphone bisa juga 
digunakan di laptop atau computer. Untuk halaman pertama di flipbook terdapat cover yang ditampilkan dengan semenarik mungkin seperti terlihat pada gambar 1

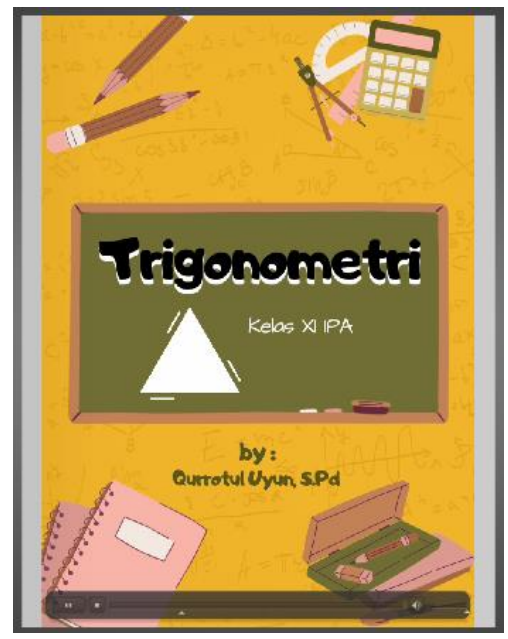

\section{Gambar 1 Cover depan flipbook trigonometri}

Halaman 2 terdapat pembukaan yang diawali dengan bismillah, halaman 3 merupakan tujuan dari pembalajaran trigonometri untuk seperti pada gambar 2 untuk halaman 4 dan 5 merupakan pengertian dari trigonometri seperti pada gambar 3 halaman 6-7 merupakan manfaat dari pembelajaran trigonometri untuk kehidupan sehari-hari seperti pada gambar 4, halaman 8-9 adalah konsep awal dari trigonometri dan dihalaman 9 terdapat video pembelajaran yang disampaikan oleh peneliti serta menjelaskan tentang sudut-sudut istimewa menggunakan tangan seperti pada gambar 5. Pada halaman 10 merupakan penjelasan dari konsep dasar trigonometri, halaman 11 menjelaskan tentang contoh soal trigonometri pada kehidupan sehari-hari seperti pada gambar 6. Halama 12 dan 13 membahas tentang kelanjutan materi konsep dasar yaitu persamaan trigonometri yang disampaikan melalui video seperti pada gambar 7. Halaman 14-15 merupakan latihan soal seperti pada gambar 8, serta halaman 16 merupakan cover belakang flipbook seperti pada gambar 9.

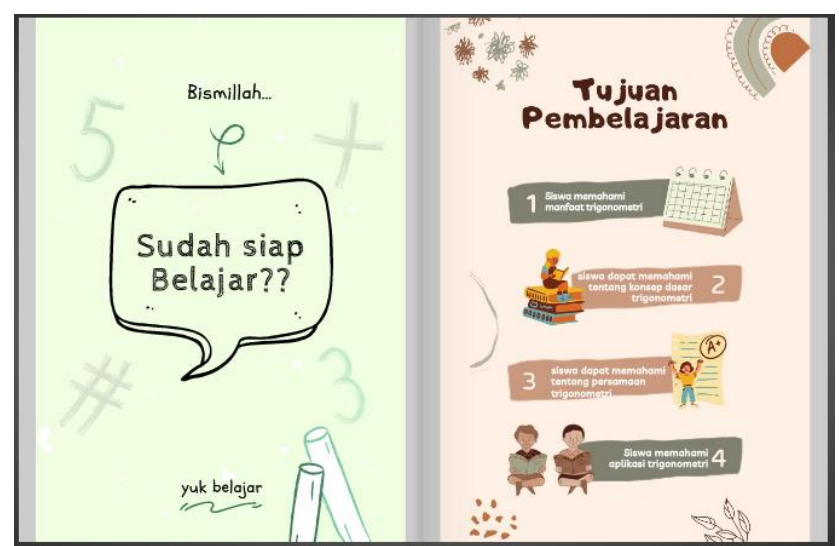

Gambar 2. Tujuan Pembelajaran

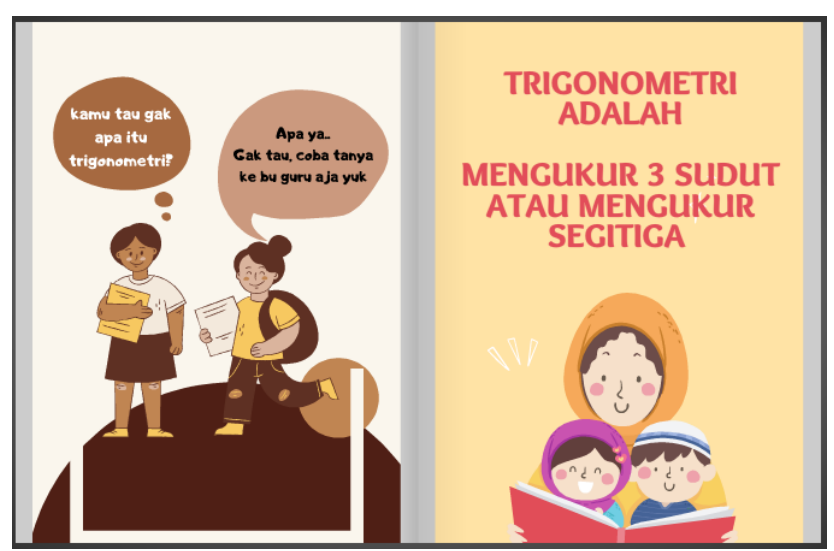

Gambar 3. Definisi Trigonometri 


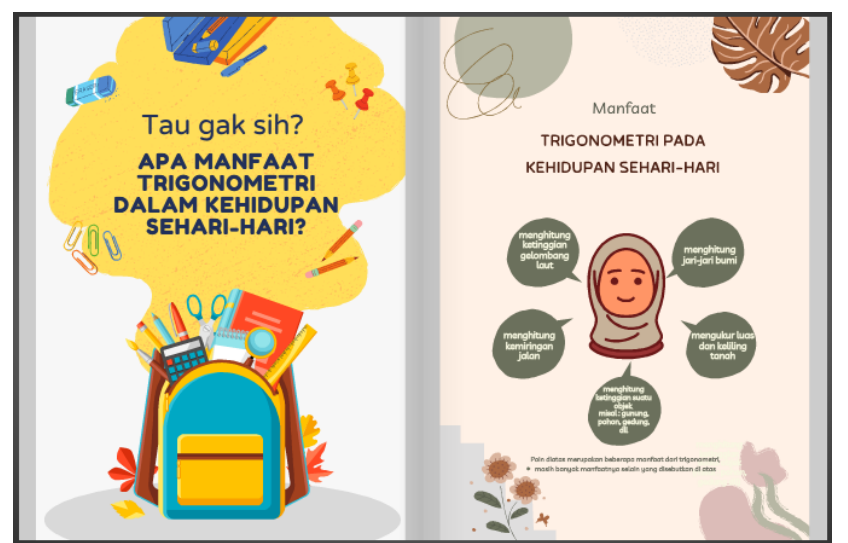

Gambar 4. Aplikasi Trigonometri

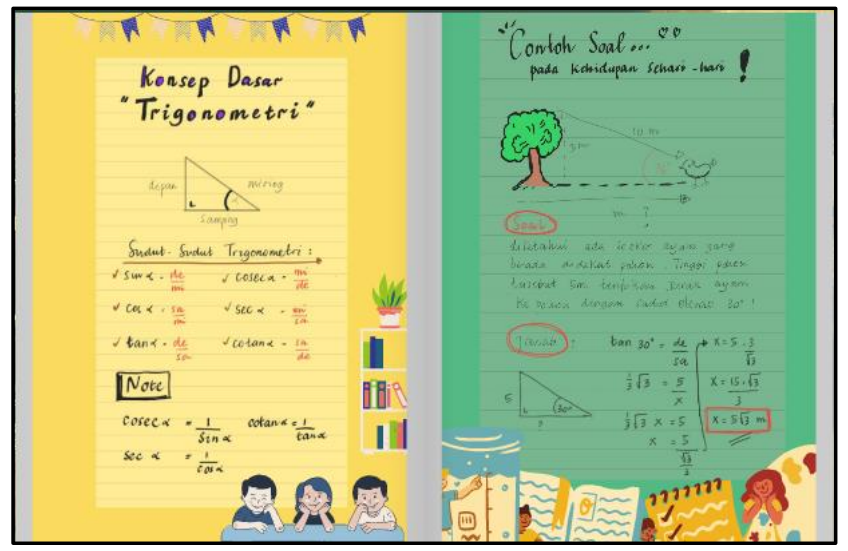

Gambar 6. Latihan soal

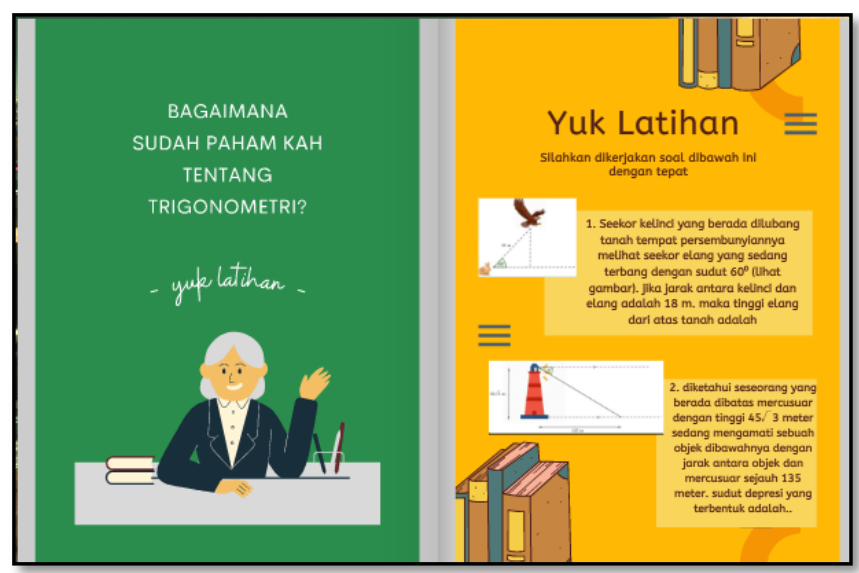

Gambar 8. Latihan Soal

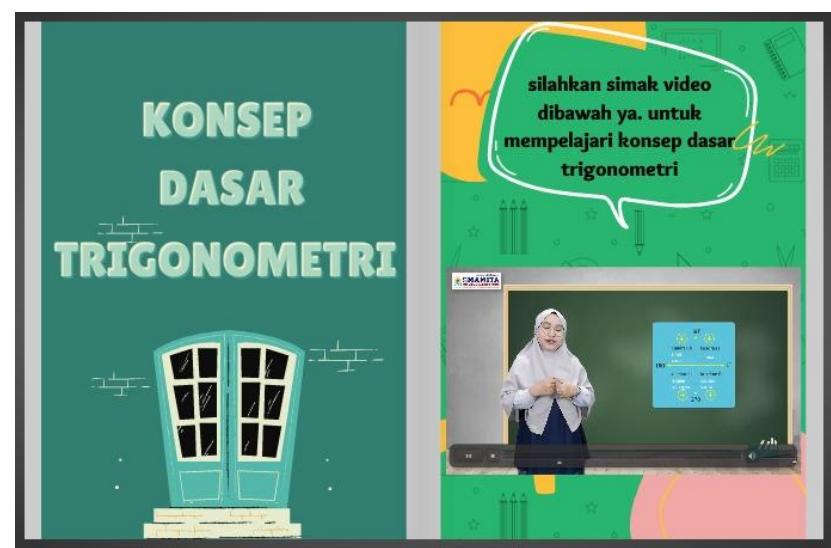

Gambar 5. Materi Konsep Dasar Trigonometri

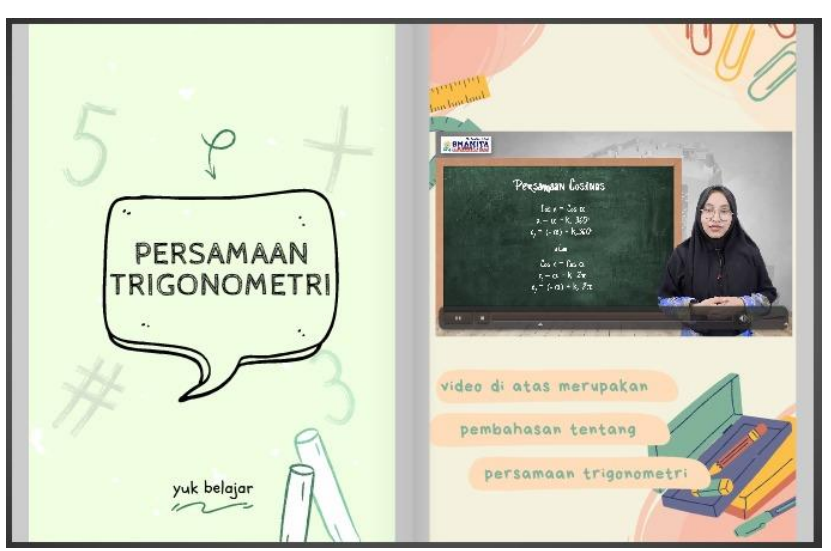

Gambar 7. Materi Persamaan Trigonomeri

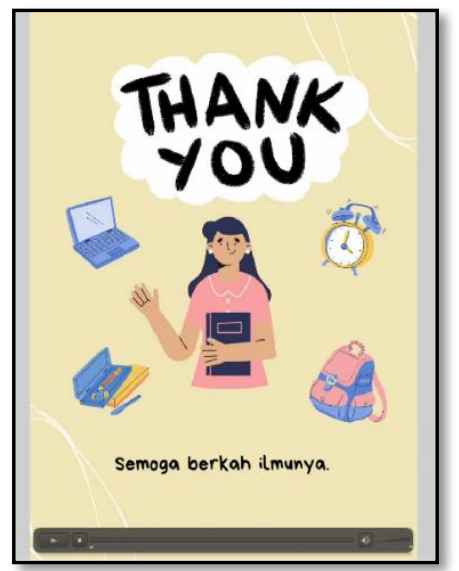

Gambar 9. Cover belakang

Video pembelajaran yang ditampilkan di flipbook dengan materi konsep dasar trigonometri dengan pembahasan materi tips dan trik dengan mudah memahami konsep sudut trigonometri. Peserta didik bisa melihat kapan saja video tersesebut dan bisa diputar berulang-ulang sesuai keinginannya. Terdapat 2 video pembelajaran yang terdapat pada flipbook yaitu video dengan kelanjutan konsep dasar trigonometri yaitu persamaan trigonometri seperti terlihat pada gambar 10 dan materi persamaan trigonometri yang terlihat pada gambar 11 


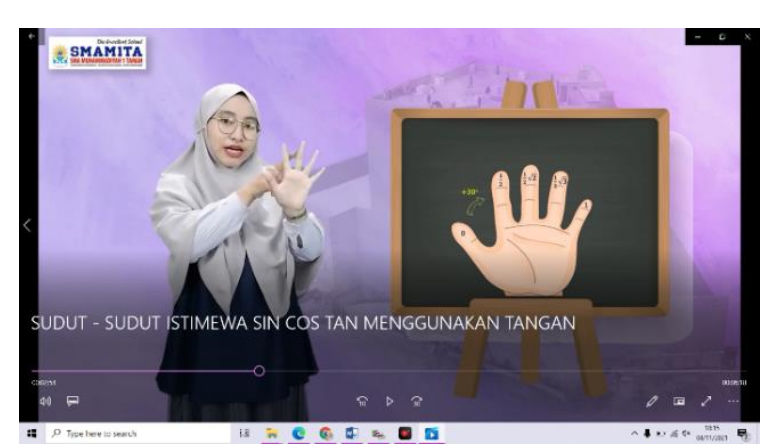

Gambar 10.

Video Konsep Dasar Trigonometri

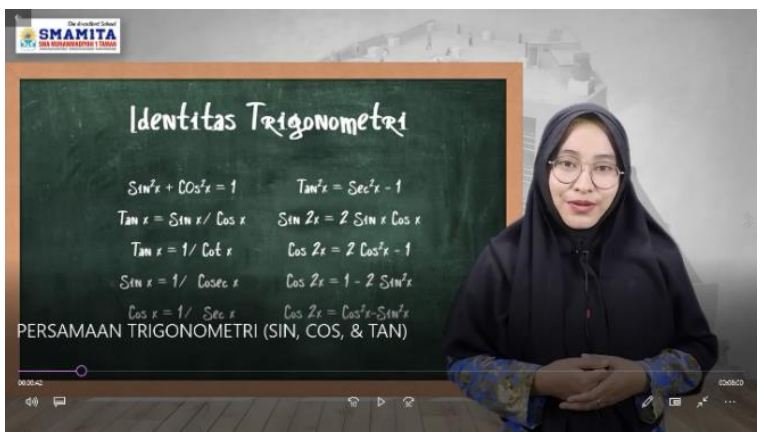

Gambar 11.

Video Pembelajaran Persaman Trigonometri

Pembelajaran menggunakan flipbook bisa digunakan untuk pembelajaran secara mandiri dirumah supaya bisa membantu peserta didik yang kendala jaringan dan kendala kuota. Penggunaan flipbook bisa dikirim melalui link atau aplikasi flipbook. Maka akan memudahkan peserta didik untuk pembelajaran daring. Disamping itu menunjang media pembelajaran daring maka isi didalam flipbook juga harus menarik dan tidak monoton, salah satu contohnya adalah lebih menekankan peserta didik belajar secara nyaman dan paham tentang materi yang disampaikan.

\section{c. Development (Pengembangan)}

Tahap pengembangan dilakukan validasi tim ahli untuk mengetahui apakah produk ebook ini layak digunakan atau diuji cobakan dengan menggunakan skala Likert dari (Sugiyono, 2017) seperti pada Tabel 5. Tim ahli pada penilaian validasi meliputi guru pengampu mata pelajaran terutama guru matematika sebagai ahli materi serta ahli desain untuk menilai hasil desain e-book yang sesuai dengan pelajaran hybrid.

Tabel 5. Hasil Validasi Tim Ahli

\begin{tabular}{|c|c|c|c|c|} 
No. & \multirow{2}{*}{ Tim Ahli } & \multicolumn{2}{c}{ Aspek yang Dinilai } & Rata-Rata \\
& & Tampilan & Fungsi & \\
\hline 1. & Ahli Materi & 4,5 & 4,3 & 4,4 (Sangat Baik) \\
\hline 2. & Ahli Desain & 4,3 & 4,2 & 4,25 (Sangat Baik) \\
\hline
\end{tabular}

Hasil validasi tim ahli didapat sebesar 4,325 dengan kategori sangat baik. Kemudian menggunakan rumus untuk menghitung nilai kevalidan e-book trigonometri sebagai berikut:

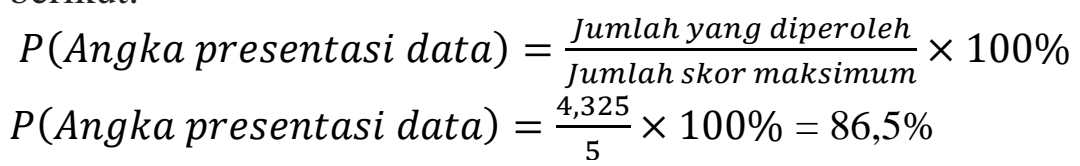

Didapat hasil 86,5\% untuk nilai kevalidan produk, berdasarkan Tabel 2 yaitu tabel kevalidan produk dapat disimpulkan e-book trigonometri menggunakan flipbook sangat layak digunakan.

\section{d. Implement (Implementasi)}

Setelah dilakukan uji validasi dan dinyatakan layak digunakan, maka tahap selanjutnya adalah uji coba produk kepada skala kecil yaitu satu kelas XI IPA SMA Muhammadiyah 1 Taman yang berjumlah 35 peserta didik. Penelitian ini dilakukan pada saat pembelajaran hybrid berlangsung dengan sebanyak 17 peserta didik melakukan tatap muka langsung dan sebanyak 18 peserta didik melakukan pembelajaran daring atau pembelajaran jarak jauh.

Guru melakukan pembelajaran hybrid dikelas dengan menggunakan zoom bagi yang daring sekaligus tatap muka langsung bagi yang luring kemudian membagi link flipbook untuk e-book trigonometri di Whatsapp. Flipbook bisa dibuka kapan saja oleh peserta didik, maka dari itu bagi peserta didik yang berhalangan hadir dan ada kendala dijaringan bisa membuka atau mempelajari e-book secara mandiri dirumah seperti halnya terlihat pada gambar 12 dan gambar 13. 


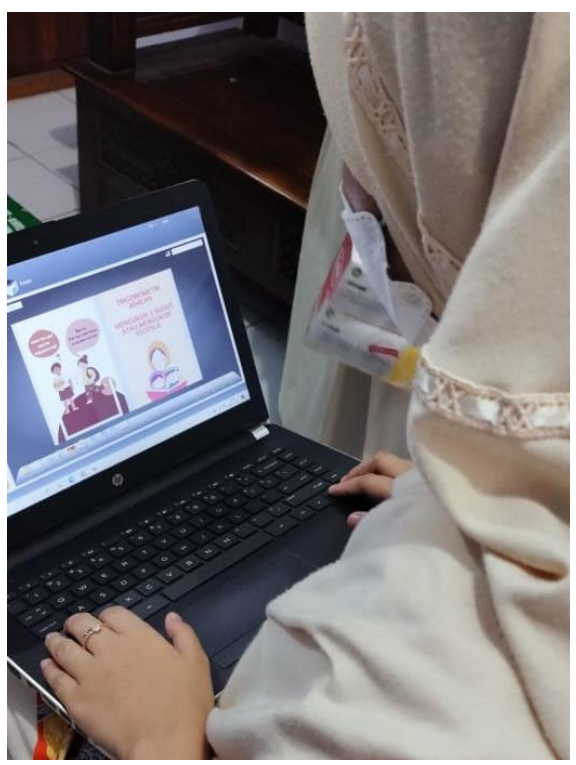

Gambar 12. Uji Coba E-book (1)

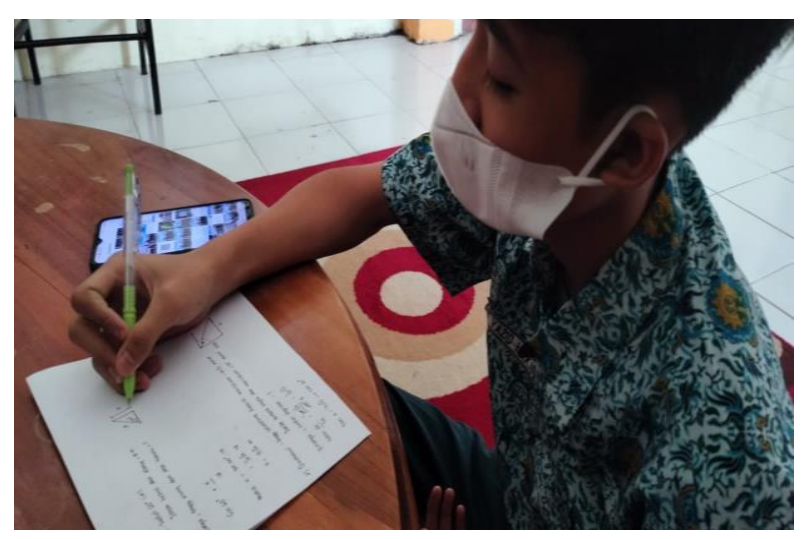

Gambar 13. Uji Coba E-book (2)

Gambar 1 dan 2 menunjukkan bahwa peserta didik bisa melakukan pembelajaran ebook diluar jam pelajaran atau belajar mandiri dirumah karena juga dilengkapi dengan latihan soal mandiri serta video audio visual yang bisa diputar atau dilihat ulang ketika peserta didik belum paham dengan materi tersebut.

e. Evaluation (Evaluasi)

Tahap Evaluasi pada penelitian ini yaitu menggunakan angket berupa googleform kepada 35 responden dan didapatkan hasi pada Tabel 6.

Tabel 6. Hasil Responden

\begin{tabular}{|c|c|c|c|c|c|c|}
\hline \multirow[t]{2}{*}{ No } & \multirow[t]{2}{*}{ Keterangan } & \multicolumn{5}{|c|}{ Hasil } \\
\hline & & SS & $\mathrm{S}$ & KS & TS & STS \\
\hline 1 & $\begin{array}{l}\text { Materi trigonometri menggunakan } \\
\text { flipbook berupa e-book audio visual } \\
\text { mudah dipahami }\end{array}$ & $\begin{array}{c}30 \\
\text { Peserta } \\
\text { didik }\end{array}$ & $\begin{array}{c}4 \\
\text { Peserta } \\
\text { didik }\end{array}$ & $\begin{array}{c}1 \\
\text { Peserta } \\
\text { didik }\end{array}$ & - & - \\
\hline 2 & $\begin{array}{l}\text { Pembelajaran menggunakan flipbook } \\
\text { berupa e-book lebih menarik dan tidak } \\
\text { membosankan }\end{array}$ & $\begin{array}{c}31 \\
\text { Peserta } \\
\text { didik }\end{array}$ & $\begin{array}{c}4 \\
\text { Peserta } \\
\text { didik }\end{array}$ & - & - & - \\
\hline 3 & $\begin{array}{l}\text { Pembelajaran hybrid menggunakan e- } \\
\text { book audio visual lebih efisien dan } \\
\text { efekfif serta menjadi alternatif media } \\
\text { pembalajaran yang menyenangkan }\end{array}$ & $\begin{array}{l}33 \\
\text { Peserta } \\
\text { didik }\end{array}$ & $\begin{array}{l}2 \\
\text { Peserta } \\
\text { didik }\end{array}$ & - & - & - \\
\hline & Rata-rata & 31,3 & 3,33 & 0,3 & - & \\
\hline
\end{tabular}

Tabel 6 dapat disimpulkan secara keseluruhan didapat rata-rata untuk yang memilih sangat setuju dalam persen menggunakan rumus :

$P($ Angka presentasi data $)=\frac{\text { Jumlah yang diperoleh }}{\text { Jumlah skor maksimum }} \times 100 \%$

$P($ Angka presentasi data $)=\frac{31,33}{35} \times 100 \%=89,5 \%$

Sebesar 89,5\% menyatakan bahwa peserta didik sangat setuju bahwa e-book audio visual trigonometri menggunakan flipbook dapat dipahami, pembelajaran menggunakan flipbook menarik serta tidak membosankan, lebih efisien dan efekfif untuk menjadi alternatif media pembalajaran yang menyenangkan di era pandemi terutama pembalajaran hybrid dalam artian mendapatkan respon yang sangat baik pada produk e-book ini.

\section{Pembahasan}

Pembahasan pada penelitian ditunjukkan pada permasalahan yang diangkat karena permasalahan yang ada di SMA Muhammadiyah 1 Taman. Permasalahan ini selanjutnya dibahas sesuai data ujicoba selama penelitian berlangsung. Berikut ini pembahasan ulang 
berawal dari rumusan masalah pada penelitian ini. Penenlitian ini dilakukan untuk mengetahui apakah media e-book audio visual menggunakan flipbook materi trigonometri kelas XI IPA SMA Muhammadiyah 1 Taman berbasis hybrid learning layak digunakan dan dikembangkan sebagai refrensi dan media pembelajaran di era pandemi khususnya pada pembelajaran hybrid. Dilihat dari validasi yang peneliti lakukan yaitu validasi tim ahli meliputi guru pengampu mata pelajaran, ahli materi dan ahli desain yang masing-masing diuji oleh guru ahli dari SMA Muhammadiyah 1 Taman., dalam tahap uji coba ini peneliti memberikan instrumen sebagai bahan penialain yang isisnya berupa materi yang digunakan pada e-book serta desain e-book audio visual berbasis hybrid learning.

Selanjutnya penelitian (Intan Widyasari, 2021) menyatakan penilaian kelayakan media pembelajaran matematika berbasis flipbook pada materi sistem persamaan linear dua variabel diperoleh rata- rata sebesar $85,70 \%$, sehingga media pembelajaran berbasis flipbook pada materi sistem persamaan linear dua variabel di kelas VIII SMP diinterpretasikan sangat valid untuk digunakan. Sehingga pada penelitian ini berdasarkan penelitian yang dilakukan menggunakan metode ADDIE untuk tingkat kelayakan produk e-book audio visual mengguanakn flipbook mendapatkan nilai secara keseluruhan adalah $86,5 \%$ dari tim ahli yang dapat disimpulkan bahwa produk layak digunakan serta mendapat kategori sangat baik. Sehingga penelitian dapat dilanjut dengan ujicoba skala kecil. Uji coba skala kecil yang meliputi 35 peserta didik kelas XI IPA SMA Muhammadiyah 1 Taman dilakukan pada pemebaljaran hybrid dikelas dengan 17 peserta didik melakukan pembalajaran secara langsung dikelas dan 18 peserta didik melakukan pembelajaran secara daring dirumah. Hasil dari uji coba dari 35 peserta didik setelah dirata-rata mendapatkan 89,5\% menyatakan bahwa e-book audio visual dapat dipahami, tidak membosankan efisien serta efektif untuk pembalajaran hybrid.

Didukung dengan hasil penelitian dari (Desi Rahamawati, 2017) yang menyatakan bahwa media pembelajaran flipbook pada materi gerak benda di SMP termasuk dalam kategori sangat valid, sangat efektif, sangat tuntas, dan dapat digunakan tanpa perbaikan dengan presentase keefektifan. Didukung juga penelitian dari (Khairinal, 2021) Berdasarkan hasil uji coba penilian angket minat belajar siswa terhadap e-book yang dikembangkan dengan rata-rata

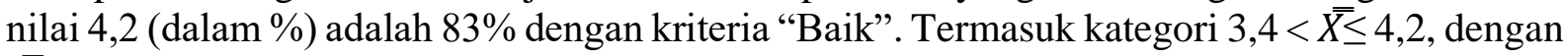
$\overline{\bar{X}}$ 3,4 dan "Tinggi". Dari tanggapan tersebut peneliti menyimpulkan bahwa e-book yang dikembangkan dapat meningkatkan minat belajar siswa. Berdasarkan hal tersebut penelitian ini membuktikan bahwa dengan adanya pengembangan media e-book audio visual pembelajaran hybrid lebih efektif untuk peserta didik kelas XI IPA SMA Muhammadiyah 1 Taman. Penelitian ini juga membuktikan bahwa media e-book audio visual layak digunakan khalayak umum dan dapat dikembangkan menjadi lebih lagi untuk mendapatkan minat belajar peserta didik yang lebih tinggi.

\section{KESIMPULAN}

Kesimpulan yang dapat dikerucutkan bahwa media e-book dengan materi trigonometri menggunakan flipbook sangat layak digunakan untuk menunjang pembelajaran hybrid dan bisa menjadi alternatif untuk pengganti zoom atau aplikasi lain. Serta didapat nilai dari tim ahli sebesar 4,325 kategori sangat baik dengan kategori kelayakan produk sebesar 86,5\% yang artinya produk e-book sangat layak digunakan dan hasil responden sebesar 89,5\% dari 35 peserta didik menyatakan e-book mudah dipahami, tidak membosankan untuk pembalajaran hybrid dan efisien serta efektif.

Tindaklanjut dari penelitian ini adalah peneliti membuat e-book dengan materi yang berbeda serta video audio yang lebih menarik lagi. Serta diharapkan menjadi resfrensi untuk para guru dalam pembelajan hybrid karena fipbook bukan hanya digunakan untuk materi matematika saja, tapi bisa digunakan untuk semua mata pelajaran. 


\section{DAFTAR PUSTAKA}

Desi Rahamawati, S. W. (2017). Pengembangan Media Pembelajaran Flipbook pada Materi Gerak Benda di SMP.

Desprayoga, V. d. (2019). PROSIDING SEMINAR NASIONAL PENDIDIKAN PROGRAM PASCASARJANA UNIVERSITAS PGRI PALEMBANG, Hal 6.

Ellington, F. P. (1988). Dalam Teknologi Pendidikan (hal. 125). Jakarta: Erlangga.

Intan Widyasari, Z. E. (2021). Pengembangan Media Pembelajaran Berbasis Flipbook pada Materi Sistem Persamaan Linear Dua Variabel Dikelas VIII SMP.

Khairinal, S. R. (2021). Pengembangan Media Pembelajaran E-Book Berbasis Flip Pdf Professional untuk Meningkatkan Kemandirian Belajar dan Minat Belajar Siswa Pada Mata Pelajaran Ekonomi Siswa Kelas X IIS 1 Sma Negeri 2 Kota Sungai Penuh.

Purnama, S. (2013). METODE PENELITIAN DAN PENGEMBANGAN (Pengenalan untuk Mengembangkan Produk Pembelajaran Bahasa Arab). LITERASI, Volume. IV, No. 1 Juni 2013, IV, 20.

Putra, T. A. (2018). In PENGEMBANGAN MEDIA PEMBELAJARAN ANIMASI BERBASIS MACROMEDIA FLASH PADA MATERI TRIGONOMETRI. Lampung: Fakultas Tarbiyah dan Keguruan Universitas Islam Negeri Raden Intan Lampung .

Sanjaya, W. (2006). Dalam Strategi Pembelajaran Berorientasi Standar Proses Pendidikan (hal. 172). Jakarta : Kencana.

Sarah, C. (2018). Pemanfaatan E-Book Sebagai Sumber Belajar Mahasiswa Stkip Bina Bangsa Getsempena Banda Aceh, 4.

Sugiyono. (2017). Dalam Metode Penelitian Pendidikan Pendekatan Kuantitatif, dan $R \& D$. Bandung: Alfabeta.

Sofyana \& Abdul. 2019. Pembelajaran Daring Kombinasi Berbasis Whatsapp Pada Kelas Karyawan Prodi Teknik Informatika Universitas PGRI Madiun. Jurnal Nasional Pendidikan Teknik Informatika. Volume 8 Nomor 1, Halm. 81-86.

Sheila Scutter, I. S. (2010). How Do Students Use Podcasts to Support Learning? Australasian Journal of Educational Technology 2010, 26(2), 180-191, 180-191.

Sukino, M. (2013). Matematika untuk SMA/MA Kelas XI Kelompok Wajib Semester 2. Penerbit Erlangga.

Martins, M. de L. (2015). How to Effectively Integrate Technology in the Foreign Language Classroom for Learning and Collaboration. Procedia - Social and Behavioral Sciences. Vol. 174, Halm. 77-84. 